\title{
Relief of pain after surgery of benign anorectal conditions: topical versus oral metronidazole
}

\author{
Mohamed Jomma Ghazala, Mohammed Mohammed El-Said, Ayman Hussein abdalhaffez \\ ,Waleed Mohamed Thabet \\ General Surgery department, Faculty of Medicine, Mansoura University, Egypt.
}

DOI: $10.21608 / \mathrm{mjmu} .2021 .101272 .1043$

\section{Submit Date:}

Accept Date:

Available online:

Keywords

- Metronidazole

- Pain

- Anorectal

- Relief

- postoperative

\begin{abstract}
Postoperative anal pain is one of the main adverse effects of surgical treatment of benign anorectal diseases and remains a distressing problem, for both patients and physicians. Postoperative pain control is important yet it remains an unresolved issue which causes patient dissatisfaction and negatively impact quality of life. This review article studied the analgesic effect of topical and oral metronidazole after benign anorectal surgery. Seven studies used oral metronidazole and six used topical metronidazole. The studies showed that post operative pain score of patients who had metronidazole by either route was significantly less than those in comparison groups. The pain score decreased at all the time points for both oral and topical metronidazole. Overall, the analgesic effect of oral metronidazole was inconsistent among published studies. When topical and oral metronidazole were compared the post operative pain score and analgesic consumption were lower in topical metronidazole than the oral group
\end{abstract}




\section{INTRODUCTION}

Anal surgeries are among the most commonly performed operations all over the world. The most common fear of patients undergoing such surgeries is the postoperative pain which can be quite annoying and may delay return to daily activities (1). Post-anal surgery pain is multifactorial; internal anal sphincter spasm, inflammation and superadded bacterial contamination of the operative site have a role (2-4). Indeed, the pain intensity has individual variation yet it's related to the extent of excision, defective wound healing and superadded infections $(5,6)$.

The use of new energy devices (Harmonic Scalpel and LigaSure) has been associated with less postoperative pain but they are expensive if compared with the conventional diathermy techniques $(7,8)$. Many pharmacologic agents (with different mechanisms of action) have been tried to decrease the post-operative pain as anesthetics, internal sphincter relaxants, opioid and non-opioid analgesics, flavonoids, sucralfate $\&$ antibiotics (9). Topical preparations are preferred over other dosage forms because of better bioavailability and fewer incidence of side effects (10). Metronidazole is a nitroimidazole member that acts against anaerobic pathogens \& protozoa and is used extensively because it is safe, cheap, efficacious, with relatively little side effects (11).

\section{Systemic and topical agents used for pain relief after anal surgery}

The use of several medications during or after anal surgery for the reduction of postoperative pain has been extensively discussed in the literature.

Analgesics and anesthetic medications: Analgesics such as ketorolac can achieve adequate control of post-hemorrhoidectomy pain, whether administered locally or systemically. Injection of ketorolac directly into the IAS fibers serves to inhibit its spasm by suppressing the prostaglandin formation in addition to its anti-inflammatory effect (12). O'Donovan and colleagues (13) reported that combined oral administration and local injection of ketorolac after hemorrhoidectomy achieved equivalent pain control to that of the narcotics group.

Local infiltration of long-acting anesthetic as bupivacaine around the skin of the anal verge can also decrease the severity of post hemorrhoidectomy pain. Haas et al. have compared among the local infiltration of Liposome Bupivacaine (LB) and bupivacaine $\mathrm{HCl}$ post hemorrhoidectomy and concluded that LB resulted in significantly decreased postoperative pain compared with bupivacaine $\mathrm{HCl}$ (14).

Sucralfate and cholestyramine: Sucralfate decreases pain post hemorrhoidectomy by promoting wound healing due to its inhibitory actions on the degradation of fibroblast and to its angiogenic actions (12). Gupta et al. found that topical sucralfate significantly reduced pain after hemorrhoidectomy up to two weeks postoperatively and provided quicker wound healing in comparision to that of a placebo group (15). The results of Gupta and colleagues were repeated by another double-blind randomized study which noticed that sucralfate ointment.

Chemical sphincterotomy: the IAS spasm was thought to be the major factor contributing to pain after hemorrhoidectomy; topical medications that induce direct relaxation of the IAS or what is called chemical sphincterotomy were tried to decrease the degree of pain after hemorrhoidectomy $(12,16)$. A literature review by Siddiqui and colleagues 
recognized three different groups of these medications: Glyceryl Trinitrate (GTN), calcium channel blockers, and botulinum toxin. The study found that the three groups were effective in pain control up to one week after hemorrhoidectomy compared to a placebo group (17).

Few trials assessed calcium channel blockers in reduction of pain after hemorrhoidectomy. Three placebo-controlled randomized trials (18). used topical diltiazem 2\%, whereas one randomized study (19) used nifedipine $0.3 \%$. While both diltiazem and nifedipine provided significantly less pain at 7 days after hemorrhoidectomy, higher rate of complications was reported, including fecal incontinence that was $2.4 \%$ after the use of Nifedipine $0.3 \%$ combined with lidocaine $1.5 \%$.

\section{The role of metronidazole in pain relief after anorectal surgery}

Metronidazole has been recognized to decrease pain after hemorrhoidectomy when administered systemically. Metronidazole is reported to relieve post-hemorrhoidectomy pain because of its antimicrobial action that reduces the bacterial colonization at the surgical sites, in addition to its anti-inflammatory effects as well. The pain-relieving effect of systemic metronidazole is debatable as Solorio-López et al (20) proved that oral administration of metronidazole $500 \mathrm{mg}$ can effectively reduce pain after hemorrhoidectomy compared with a placebo. In contrast, Khan and colleagues (21) concluded that prophylactic antibiotics, including metronidazole, have no tangible role in pain relief after open hemorrhoidectomy. Additionally, Balfour et al (22) disclosed that the systemic application of metronidazole 400mg three time per day after closed hemorrhoidectomy did not reduce the postoperative pain.

Topical metronidazole ointment has the privilege of higher tissue concentration along with less systemic side effect than the oral medication. In placebo-controlled randomized study, Ala and affiliates (23) found that topical application of metronidazole $10 \%$ significantly reduced discomfort after hemorrhoidectomy up to 14 days, and alleviated postoperative pain during defecation as compared to the placebo group. Nicholson and Armestrong (24) also reported significant reduction of posthemorrhoidectomy discomfort and edema after using topical metronidazole $10 \%$.

Another topical antimicrobial that was devised for the reduction of post-hemorrhoidectomy pain is triclosan which was investigated in a multi-center double blind randomized trial (25) and was found to improve the control of postoperative symptoms, including pain, and wound healing compared to sodium hypochlorite.

Table 1 summarizes the outcome of different trials that examined the impact of topical and oral metronidazole on pain relief after anorectal surgery.

\section{Conclusions}

Topical metronidazole appears to have a more consistent analgesic effect after surgery for benign anorectal condition, namely hemorrhoidectomy, when compared to oral metronidazole. 
Table 1. Summary of studies that assessed the analgesic effect of topical and oral metronidazole:

\begin{tabular}{|c|c|c|c|c|}
\hline Study & operation & Metronidazole & Comparator & Conclusion \\
\hline $\begin{array}{l}\text { Carapeti et al., } \\
1998(29)\end{array}$ & Haemorrhoidectomy & Oral & Placebo & $\begin{array}{l}\text { Oral metronidazole was associated with } \\
\text { significantly less pain and analgesia } \\
\text { consumption than the placebo group. } \\
\text { Return to work or to normal activity in the } \\
\text { metronidazole group was also } \\
\text { significantly earlier than in the placebo } \\
\text { group }\end{array}$ \\
\hline $\begin{array}{l}\text { Balfour et al., } \\
2002(22)\end{array}$ & Haemorrhoidectomy & Oral & Placebo & $\begin{array}{l}\text { The use of oral metronidazole did not } \\
\text { reduce postoperative pain. }\end{array}$ \\
\hline $\begin{array}{l}\text { Niclson, T., and } \\
\text { Armstrong, D., } \\
\text { 2004(24) }\end{array}$ & Haemorrhoidectomy & Topical & Placebo & $\begin{array}{l}\text { Topical metronidazole significantly } \\
\text { reduced pain post hemorrhoidectomy at } \\
\text { days } 7 \text { and } 14 \text { postoperatively. } \\
\text { Postoperative edema was reduced and } \\
\text { overall healing was improved, compared } \\
\text { to that of placebo. }\end{array}$ \\
\hline $\begin{array}{l}\text { Ala, S. et al., } \\
\mathbf{2 0 0 8}(23)\end{array}$ & Haemorrhoidectomy & Topical & Placebo & $\begin{array}{l}\text { Topical metronidazole significantly } \\
\text { reduced post-hemorrhoidectomy } \\
\text { discomfort, defecation pain and narcotic } \\
\text { consumption as compared to that of } \\
\text { placebo group }\end{array}$ \\
\hline $\begin{array}{l}\text { lopez et al., } \\
2015(20)\end{array}$ & hemorrhoidectomy & Oral & Placebo & $\begin{array}{l}\text { Metronidazole was effective in pain } \\
\text { management after hemorrhoidectomy in } \\
\text { comparison to the placebo with less need } \\
\text { of rescue analgesia. }\end{array}$ \\
\hline $\begin{array}{l}\text { Shamsa., } \\
\text { 2015(28) }\end{array}$ & $\begin{array}{l}\text { Haemorrhoidectomy } \\
\text { And } \\
\text { fistulectomy }\end{array}$ & Topical & Placebo & $\begin{array}{l}\text { Topical metronidazole was effective in } \\
\text { reducing post-operative pain in anal } \\
\text { surgeries, reducing on-defecation pain, } \\
\text { decreasing analgesic requirements. }\end{array}$ \\
\hline $\begin{array}{c}\text { Lyons et al } \\
2017(30)\end{array}$ & haemorrhoidectomy & Topical and oral & Placebo & $\begin{array}{l}\text { Metronidazole reduced postoperative pain } \\
\text { following hemorrhoidectomy and pain on } \\
\text { first defecation more than placebo }\end{array}$ \\
\hline $\begin{array}{l}\text { Neogi et al., } \\
2018(26)\end{array}$ & hemorrhoidectomy & Topical \& oral & Placebo & $\begin{array}{l}\text { Metronidazole in the form of oral or } \\
\text { topical preparation resulted in better pain } \\
\text { relief and less use of analgesic drugs } \\
\text { postoperatively and therefore could } \\
\text { correlate to earlier return to daily life } \\
\text { activities as compared to its } \\
\text { administration as preoperative antibiotic }\end{array}$ \\
\hline $\begin{array}{l}\text { Angelina et al., } \\
2019(31)\end{array}$ & Haemorrhoidectomy & Oral & Placebo & $\begin{array}{l}\text { There was reduction in VAS score across } \\
\text { all time points whereas there was no } \\
\text { difference in return to work and normal } \\
\text { daily activities and analgesia consumption } \\
\text { between the oral metronidazole and } \\
\text { control groups }\end{array}$ \\
\hline $\begin{array}{l}\text { Abbas et al., } \\
2020(27)\end{array}$ & Haemorrhoidectomy & Topical & $\begin{array}{c}\text { Oral } \\
\text { metronidazole }\end{array}$ & $\begin{array}{l}\text { The mean pain score after topical } \\
\text { metronidazole is less than oral } \\
\text { metronidazole }\end{array}$ \\
\hline
\end{tabular}

\section{Reference:}

\section{[1] Gordon's principles and practice of surgery}

for the colon, rectum and anus, 3 rd edition, pages $157,182-183$

\section{[2] Habeeb F, Shakir E, Bradbury F, et al.} Screening methods used to determine the antimicrobial properties of Aloe vera inner gel.

Methods 2007;42:315-320.
[3] Maenthaisong R, Chaiyakunapruk N, Niruntraporn S , Kongkaew C. The efficacy of Aloe vera used for burn wound healing: A systematic review. Burns 2007;33:713-718.

[4] Nicholson T, Armstrong D. Topical metronidazole (10 percent) decreases posthemorrhoidectomy pain and improves healing. Dis Colon Rectum 2004;47:711-716. 
[5] Riss S, Weisser FA, SchwameisK, etal.The prevalence of hemorrhoids in adults.Int $\mathrm{J}$ Colorectal Dis2012;27:215-

20.DOI:10.1007/s00384-011-1316- 3.

[6] de Paula PR, SperanziniMB, HamzagicHC, et al. Bacteriology of the anal wound after open hemorroidectomy.Qualitative and quantitative analysis.Dis Colon Rectum 1991;34:664-9. DOI:10.1007/BF02050347.

[7] Chung CC, Ha JP, Tai YP, Tsang WW, Li MK.A double-blind, randomized trial comparing Harmonic Scalpel Hemorroidectomy, bipolar scissors hemorroidectomy and scissors excision: ligation technique, Dis Colon Rectum 2002;45:789-794.

[8] Kwok SY, Chung CC, Tsui KK, Li MK.A doubleblind, randomized trial comparing LigaSure and Harmonic Scalpel Hemorroidectomy. Dis Colon Rectum 2005;48;344-348.

[9] Sammor T, Barazanchi AWH, Hill AG.Evidencebased management of pain after excisional hemorroidectomy surgery.A PROSPECT Review Upadate.WourldJSurg. DOI: 10.1007/s00268-016- 3737-1.

[10]RahimiR, Abdollahi M.A systemic review of the topical drugs for post- hemorroidectomy pain. International Journal of pharmacology 2012;7;628- 638. ISSN 18117775/DOI:10.3923/ijp.2012.628.637.

[11]Neshige S, KanayaY, Takeshima S, et al.Reversible changes on MRI in a patient with metronidazole induced encephalopathy.RinshoShinkeigaku 2015;55:1477.DOI:10.5692/clinicalneurol.55.174.
[12]. Yang HK. Perioperative management. In: Yang HK, editor. Hemorrhoids. Berlin Heidelber: Springer-Verlag; 2014.

[13]. O'Donovan S, Ferrara A, Larach S, Williamson P. Intraoperative use of toradol facilitates outpatient hemorrhoidectomy. Dis Colon Rectum. 1994;37:793-9.

[14]. Haas, E. ; Onel, E. ; Miller, H. ; Ragupathi, M. and White, P. F. A doubleblind, randomized, active-controlled study for post- hemorrhoidectomy pain management with liposome bupivacaine, a novel local analgesic formulation. The American Surgeon, 2012. 78(5),574-581.

[15]. Gupta, P. ; Heda, P. ; Kalaskar, S. and Tamaskar, V. Topical sucralfate decreases pain after hemorrhoidectomy and improves healing: a randomized, blinded, controlled study. Diseases of the colon \& rectum, 2008. 51(2), 231-234.

[16]. Lohsiriwat, D. and Lohsiriwat, V. Outpatient hemorrhoidectomy under perianal anesthetics infiltration. JOURNAL-MEDICAL ASSOCIATION OF THAILAND, (2005). 88(12), 1821.

[17]. Siddiqui, M. R. S. ; Abraham-Igwe, C. ; Shangumanandan, A. ; Grassi, V.; Swift, I. and Abulafi, A. M. A literature review on the role of chemical sphincterotomy after Milligan-Morgan hemorrhoidectomy. International journal of colorectal disease, 2011. 26(6), 685-692.

[18]. Amoli, H. ; Notash, A. ; Shahandashti, F. ; Kenari, A. and Ashraf, H. A randomized, prospective, double-blind, placebo- controlled trial of the effect of topical diltiazem on 
posthaemorrhoidectomy pain. Colorectal

Disease, 2011. 13(3), 328-332.

[19]. Sugimoto, T. ; Tsunoda, A. ; Kano, N. ; Kashiwagura, Y. ; Hirose, K.-i. and Sasaki, T. A randomized, prospective, double-blind, placebo-controlled trial of the effect of diltiazem gel on pain after hemorrhoidectomy. World journal of surgery, 2013. 37(10), 2454-2457.

[20]. Solorio-López S, Palomares-Chacón UR, Guerrero-Tarín JE, González-Ojeda A, Cortés-Lares JA, Rendón-Félix J, et al. Efficacy of metronidazole versus placebo in pain control after hemorrhoidectomy. Results of a controlled clinical trial. Rev Esp Enferm Dig. 2015;107:681-5.

[21]. Khan KI, Akmal M, Waqas A, Mahmood S. Role of prophylactic antibiotics in Milligan Morgan hemorrhoidectomy - a randomized control trial. Int J Surg. 2014;12:868-71.

[22]. Balfour L, Stojkovic SG, Botterill ID, Burke DA, Finan PJ, Sagar PM. A randomized, double-blind trial of the effect of metronidazole on pain after closed hemorrhoidectomy. Dis Colon Rectum. 2002;45:1186-90.

[23]. Ala S, Saeedi M, Eshghi F, Mirzabeygi P. Topical metronidazole can reduce pain after surgery and pain on defecation in postoperative hemorrhoidectomy. Dis Colon Rectum. 2008;51:235-8.

[24]. Nicholson TJ, Armstrong D. Topical metronidazole (10 percent) decreases posthemorrhoidectomy pain and improves healing. Dis Colon Rectum. 2004;47:711-6.

[25]. Giannini I, Pecorella G, Pennisi D, Santangelo G, Digennaro R, Latorre F, et al. Control of post-hemorrhoidectomy symptoms and wound healing by Triclosan: a randomized, double-blind, controlled trial. Minerva Chir. 2014;69:75-82

[26]. Neogi $P$, Sinha A, Singh $M$. Is metronidazole a panacea for post hemorrhoidectomy pain? Int Surg J. 2018. 5(11),3598- 3601.

[27]. Abbas ST, Raza A, Muhammad Ch I, Hameed T, Hasham N, Arshad $N$. Comparison of mean pain score using topical and oral metronidazole in post Milligan Morgan hemorrhoidectomy patient; Pak J Med Sci. 2020. 36(5),867-871.

[28]. Shamssa, M.S. (2018). Topical Metronidazole for Post-Anal Surgery Pain.

[29]. Carapeti, E. ; Kamm, M. ; McDonald, P. ; CHADWICK, S. D. and PHILLIPS, R. S. Randomized trial of open versus closed daycase haemorrhoidectomy. British journal of surgery, 1999. 86(5), 612-613.

[30]. Lyons NJR, Cornille JB, Pathak S, Charters P, Daniels IR, Smart NJ. the role of metronidazole in post-haemorrhoidectomy pain relief. Colorectal Dis. 2017.19(9),803811.

[31]. Di Re, Angelina \& Toh, James \& Iredell, Jonathan \& Con Ctercteko, Grahame. Metronidazole in the Management of PostOpen Haemorrhoidectomy Pain: Systematic Review. Annals of Coloproctology. 2020. 36. 5-11. 10.3393/ac. 